\title{
ANALISIS PEMAHAMAN MAHASISWA PENDIDIKAN FISIKA UNIVERSITAS JEMBER PADA MATERI TEKNOLOGI RADIASI IONIZING DALAM PENGAWETAN BAHAN PANGAN
}

\author{
1) Ahmad Nor Hamidy, ${ }^{1)}$ Sudarti, ${ }^{1)}$ Trapsilo Prihandono \\ ${ }^{1)}$ Program Studi Pendidikan Fisika FKIP Universitas jember \\ Email : ahmadnorhamidy@gmail.com
}

\begin{abstract}
Most Physics Education students do not know about ionizing radiation technology in food preservation. This research aims to determine and analyze the ability of physics education students at the University of Jember in understanding ionizing radiation technology in food preservation. The research method used is descriptive research. Technique of data collection was a questionnaire method to 50 physics education students at the University of Jember. The research variable is students' knowledge of ionizing radiation technology as food preservation. The data collection technique used is by giving 10 multiple choice questions to 50 students of Physics Education. The results of student answers will be analyzed and represented in the form of tables and pie charts.
\end{abstract}

Key word: Student Understanding, Foodstuffs, Ionizing Irradiation

\section{PENDAHULUAN}

Bahan pangan adalah semua jenis bahan baku hasil pertanian, perkebunan atau peternakan yang dapat di konsumsi secara langsung maupun dikelola menjadi produk lain. Bahan pangan dibedakan menjadi dua, yaitu bahan pangan hewani dan bahan pangan nabati. Bahan pangan hewani adalah bahan pangan yang bersumber dari hewan, misalnya susu, daging, dan telur. Sedangkan bahan pangan nabati adalah bahan pangan yang bersumber dari tumbuhan, seperti kacang-kacangan, sayuran, dan buah-bahan. Bahan pangan termasuk kebutuhan utama bagi manusia karena tanpa bahan pangan manusia tidak bisa bertumbuh dan bertahan hidup. Bahan pangan merupakan sumber gizi bagi manusia yang akan berperan penting bagi kesehatan dan kebugaran tubuh. Tetapi bahan pangan juga merupakan sumber makanan bagi mikroba ataupun bakteri yang dapat menimbulkan penyakit (patogen).

Peristiwa keracunan pangan atau foodborne disease yang disebabkan oleh bakteri patogen masih menjadi masalah yang serius di berbagai negara termasuk Indonesia. Indonesia merupakan salah satu negara penghasil bahan pangan terbanyak, karena sebagian besar penduduknya bermata pencaharian sebagai petani. Oleh karena itu, Indonesia disebut sebagai negara agraris. Sejak zaman dahulu sudah banyak teknik pengelolaan dan pengawetan bahan pangan agar kualitas bahan pangan tetap terjaga dengan jangka waktu yang lama. Misalnya dengan teknik pendinginan, pengeringan, pengasinan dan pembekuan. Namun di zaman modern ini teknik pengawetan bahan 
pangan semakin berkembang. Salah satunya yaitu teknik radiasi menggunakan sinar gamma. Iradiasi bahan pangan adalah salah satu teknik pengolahan bahan pangan yang memiliki tujuan untuk menguragi ataupun membunuh berbagai macam cemaran biologis seperti bakteri patogen (penyebab penyakit), jamur, virus, dan serangga yang dapat merusak kualitas dari bahan pangan pangan serta membahayakan orang-orang yang mengkonsumsi dengan cara memancarkan ion (mengionisasi) bahan pangan tersebut dengan menggunakan sinar tertentu. Iradiasi juga bermanfaat untuk mencegah proses penuaan pada bahan pangan, misalnya pertunasan. Sehingga bahan pangan akan terlihat tetap segar dengan jangka waktu yang cukup lama. Iradiasi pada bahan pangan banyak diterapkan karena menggunakan energi elektromagnetik tertentu, yaitu energi radiasi ppengion. Radiasi pengion (ionizing) merupakan radiasi yang dapat menghasilkan sejumlah ion pada saat berinteraksi dengan atom atau molekul yang lain dengan menggunakan energi yang cukup.

Contoh radiasi pengion antara lain, radiasi sinar alpha $(\alpha)$, sinar beta $(\beta)$ sinar gamma $(\gamma)$ dan radiasi ultraviolet. Dari berbagai jenis radiasi pengion tersebut, jenis radiasi yang paling sering digunakan pada pengawetan bahan pangan adalah radiasi sinar gamma. Sinar gamma sering digunakan karena memiliki gelombang elektromagnetik yang bergerak dengan kecepatan tinggi dan hampir menyamai kecepatan cahaya, jarak lintasan relatif panjang, arahnya tidak dipengaruhi medan magnet, tidak memiliki muatan dan mempunyai daya ionisasi kecil serta daya tembus yang tinggi. Para peneliti lebih sering menggunakan radiasi sinar gamma dalam melakukan penelitian terhadap bahan pangan, karena sinar gamma tidak bermassa dan tidak bermuatan. Besar radiasi yang diterima oleh suatu bahan disebut dosis radiasi. Dosis radiasi dapat dihitung secara matematis dengan menggunakan persamaan $: \mathrm{D}=\mathrm{L}_{\mathrm{d}} \mathrm{t}$. Dengan $\mathrm{D}$ adalah dosis radiasi dalam satuah Gray (Gy), $\mathrm{L}_{\mathrm{d}}$ adalah laju dosis dalam satuan Gy/s, dan $\mathrm{t}$ adalah lama penyinaran radiasi dalam satuan sekon (s).

Materi tentang radiasi non pengion dan pengion dipelajari pada mata kuliah fisika lingkungan yang ditempuh oleh mahasiswa pendidikan Fisika semester V di FKIP Universitas Jember. Untuk memahami materi tersebut dibutuhkan kemampuan berpikir yang baik. Kemampuan berfikir adalah kegiatan penalaran yang kritis, reflektif dan kreatif yang berorientasi pada suatu proses intelektual yang melibatkan pembentukan konsep (conceptualizing), aplikasi, analisis, menilai informasi yang terkumpul (sintesis) atau dihasilkan melalui pengamatan, pengalaman, refleksi, komunikasi sebagai landasan kepada suatu keyakinan (kepercayaan) dan tindakan (Iskandar, 2009: 86).

Kemampuan berpikir kritis sangat penting untuk selalu ditingkatkan terutama oleh mahasiswa calon guru fisika dalam menyelesaikan berbagai macam soal fisika. Karena fisika adalah salah satu mata pelajaran yang membutuhkan ketelitian tingkat tinggi. Kemampuan berpikir kritis dapat dilatih dan dikembangkan melalui proses pembelajaran baik di dalam kelas maupun di luar kelas. Selain menggunakan pengembangan kemampuan kognitif, pembelajaran juga dapat menggunakan kemampuan berpikir kritis mahasiswa. Pengembangan kemampuan berpikir kritis pada mahasiswa dapat dilakukan dengan beberapa cara seperti mendorong mahasiswa untuk melakukan diskusi dan berpendapat dengan logis, memberikan kesempatan kepada mahasiswa untuk mengekspresikan diri, memberikan rangsangan kepada mahasiswa untuk menjawab pertanyaan serta membuat gagasan dalam bentuk tulisan 
maupun lisan. Pemahaman mahasiswa Pendidikan Fisika sebagai calon guru fisika dalam memahami konsep dan materi radiasi sangat penting karena akan mempengaruhi tercapainya tujuan pembelajaran bagi siswa. Oleh karena itu peneliti terdorong untuk melakukan penelitian berupa survey atau kuisioner tentang pemahaman mahasiswa terhadap materi radiasi ionizing pada bahan pangan.

\section{METODE}

Metode penelitian yang digunakan yaitu metode deskriptif dengan pendekatan kuantitatif. Peneliti menggunakan metode ini karena akan mendeskripsikan kemampuan dan pemahaman mahasiswa pendidikan fisika dalam memahami materi radiasi ionizing (pengion) pada bahan pangan. Subjek pada penelitian ini adalah mahasiswa pendidikan fisika Universitas Jember sebanyak 50 mahasiswa. Teknik yang digunakan dalam pengambilan data adalah dengan cara memberikan 10 soal pilihan ganda (multiple choice) dari tingkatan yang mudah hingga sulit terkait dengan materi teknologi radiasi ionizing pada pengawetan bahan pangan yang dikerjakan melalui google form yang sudah disediakan oleh peneliti. Hasil tes kemudian akan direpresentasikan dalam bentuk tabel dan diagram lingkaran untuk mempermudah dalam menganalisis dan melihat data.

\section{HASIL DAN PEMBAHASAN}

Soal tes yang diberikan kepada 50 responden adalah soal pilihan ganda sebanyak 10 butir yang diisi oleh Mahasiswa Pendidikan Fisika Universitas Jember. Adapun distribusi hasil jawaban responden tiap soal dapat dilihat pada Tabel 1 berikut: Tabel 1. Distribusi Hasil Jawaban Responden

\begin{tabular}{llll}
\hline $\begin{array}{l}\text { No. } \\
\text { Soal }\end{array}$ & $\begin{array}{l}\text { Jawaban } \\
\text { Benar }\end{array}$ & $\begin{array}{l}\text { Jawaban } \\
\text { Salah }\end{array}$ & Total \\
\hline 1 & 43 & 7 & 50 \\
\hline 2 & 21 & 29 & 50 \\
\hline 3 & 20 & 30 & 50 \\
\hline 4 & 33 & 17 & 50 \\
\hline 5 & 11 & 39 & 50 \\
\hline 6 & 19 & 31 & 50 \\
\hline 7 & 17 & 33 & 50 \\
\hline 8 & 29 & 21 & 50 \\
\hline 9 & 8 & 42 & 50 \\
\hline 10 & 11 & 39 & 50 \\
\hline
\end{tabular}

Sedangkan data nilai mahasiswa Pendidikan Fisika dapat dilihat pada diagram lingkaran Gambar 1 berikut :

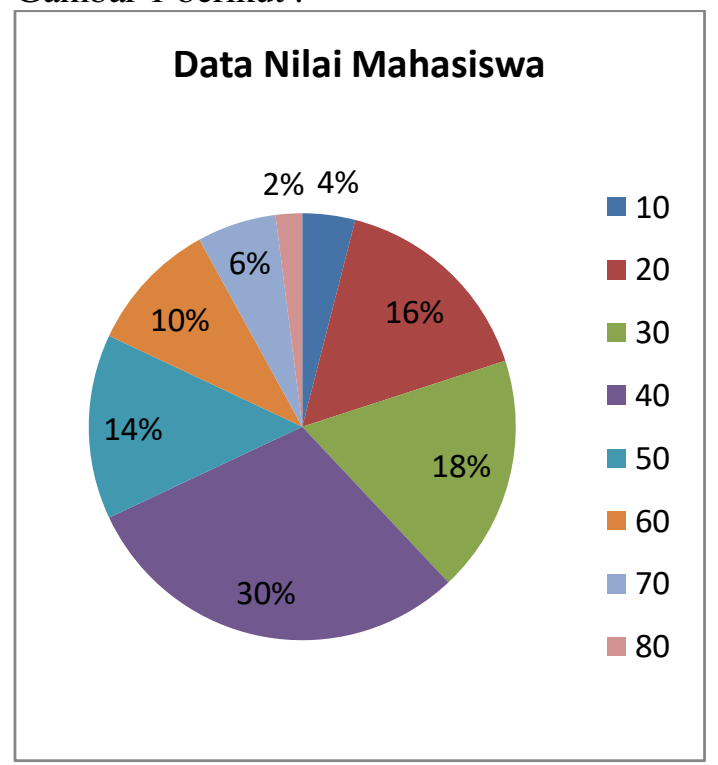

Gambar 1. Data Nilai Mahasiswa

Dari data tersebut diketahui bahwa pemahaman mahasiswa Pendidikan Fisika masih tergolong cukup rendah. Karena dari 50 mahasiswa yang menjadi responden terdapat 2 mahasiswa yang memperoleh nilai 10,8 mahasiswa memperoleh nilai 20, 9 mahasiswa memperoleh nilai 30, 15 mahasiswa 
memperoleh nilai 40, 7 mahasiswa memperoleh nilai 50, 5 mahasiswa memperoleh nilai 60, 3 mahasiswa memperoleh nilai 70 , dan 1 mahasiswa memperoleh nilai 80 .

Pertama, soal nomor 1 mencakup tentang pengertian teknologi radiasi ionizing. Jawaban yang benar pada soal nomor 1 adalah opsi $\mathrm{C}$ yaitu "Radiasi pengion (ionizing) merupakan radiasi yang dapat menghasilkan sejumlah ion pada saat berinteraksi dengan atom atau molekul yang lain dengan menggunakan energi yang cukup". Pada soal ini sebanyak 43 mahasiswa menjawab dengan benar. Soal ini tergolong mudah karena hanya memilih pengertian atau definisi yang tepat dari radiasi ionizing.

Soal nomor 2 mencakup tentang hal-hal yang tidak termasuk keunggulan iradiasi gamma pada produk bahan pangan. Jawaban yang benar adalah opsi $\mathrm{C}$ yaitu "Tidak dapat memproses produk secara komersial". Karena seharusnya iradiasi gamma dapat memproses produk secara komersial. Pada soal ini sebanyak 21 mahasiswa menjawab dengan benar. Soal ini tergolong sedang karena mahasiswa harus memahami keunggulan dan kelemahan dari iradiasi gamma.

Soal nomor 3 mencakup tentang cara yang digunakan pada aplikasi kombinasi teknologi iradiasi gamma dan penyimpanan beku yang berpotensi untuk menurunkan bakteri patogen pada produk seafood. Jawaban yang benar adalah opsi B yaitu "Terhambatnya aktivitas mikroba karena DNA bakteri telah rusak". Pada soal ini sebanyak 20 mahasiswa menjawab dengan benar. Soal ini tergolong cukup sulit karena mahasiswa harus memahami lebih dalam tentang aplikasi iradiasi ionizing.
Soal nomor 4 mencakup tentang alasan mengapa penggunaan kombinasi iradiasi gamma dan penyimpanan beku sudah terbukti aman. Jawaban yang tepat adalah opsi B yaitu "Mampu meningkatkan keamanan produk serta tidak menimbulkan sifat radioaktif tanpa mengubah kualitas sensoris pada produk olahan seafood'. Pada soal ini sebanyak 33 mahasiswa menjawab dengan benar. Soal ini masih tergolong mudah karena hanya mencari alasan yang logis dan tepat dari opsi yang sudah tersedia.

Soal nomor 5 mencakup tentang hal pertama yang harus dilakukan pada saat melakukan teknik pengawetan telur ayam broiler menggunakan radiasi ionizing. Jawaban yang tepat adalah opsi B yaitu "Membungkus telur ayam broiler dengan plastik tersegel". Pada soal ini hanya 11 mahasiswa yang menjawab dengan benar. Soal ini termasuk sedang karena mahasiswa harus menentukan hal pertama yang harus dilakukan pada saat melakukan pengawetan pada telur ayam broiler.

Soal nomor 6 mencakup tentang faktor-faktor yang menentukan tingkat efektivitas dan efisiensi proses radiasi pada bahan pangan. Jawaban yang tepat adalah opsi C yaitu "Sifat ekstrinsik bahan pangan" karena yang mempengaruhi efektivitas dan efisiensi adalah sifat ekstrinsik bahan pangan, seperti kandungan apa saja yang terdapat pada bahan. Pada soal ini yang dapat menjawab dengan benar ada 19 mahasiswa. Soal ini tergolong sedang karena mahasiswa harus memahami lebih dalam terkait faktor pendukung dan penghambat efektivitas dan efisiensi radiasi pada bahan pangan. 
Soal nomor 7 mencakup tentang syarat bahan pangan yang harus terpenuhi sebelum di iradiasi. Jawaban yang benar adalah opsi B yaitu "Kualitas bahan pangan prima/lolos GMP”. Karena jika bahan pangan itu tidak lolos seleksi GMP akan berpengaruh terhadap efektivitas bahan pangan setelah di iradiasi. Pada soal ini sebanyak 17 mahasiswa menjawab dengan benar. Soal ini tergolong sedang karena mahasiswa harus mengetahui syarat bahan pangan yang baik agar bisa di iradiasi.

Soal nomor 8 mencakup tentang hal yang tidak perlu dikaji sebelum melakukan teknik pengawetan pada bahan pangan. Jawaban yang tepat adalah opsi A yaitu "Aktivitas petani". Jawaban ini benar karena tidak dijelaskan secara spesifik apa saja aktivitas petani yang dilakukan. Pada soal ini cukup banyak mahasiswa yang menjawab dengan tepat yaitu sejumlah 29 mahasiswa karena soal ini tergolong mudah.

Soal nomor 9 mencakup tentang jenis bahan pangan dan penggunaan dosis yang benar. Jawaban yang tepat adalah opsi D yaitu "Biji-bijian dengan dosis 5 kGy untuk menghilangkan serangga dan bakteri patogen". Pada soal ini hanya ada 8 mahasiswa yang menjawab dengan benar. Soal ini tergolong cukup sulit karena mahasiswa harus memahami jenis bahan pangan serta dosis radiasi yang tepat untuk mengawetkan bahan pangan tersebut.

Soal nomor 10 mencakup tentang penggunaan dosis iradiasi ionizing yang tepat dan fungsinya bagi bahan pangan. Jawaban yang tepat adalah opsi A yaitu "Dosis rendah $(\leq 1 \quad \mathrm{kGy})$ dapat dimanfaatkan untuk menunda pematangan buah dan menghambat pertunasan". Pada soal ini terdapat 11 mahasiswa yang menjawab dengan benar. Soal ini tergolong sedang karena mahasiswa harus mengetahui macammacam dosis iradiasi ionizing dan fungsinya yang tepat pada bahan pangan.

\section{SIMPULAN DAN SARAN}

Berdasarkan analisis hasil jawaban mahasiswa Pendidikan Fisika Universitas Jember terhadap kuisioner tentang teknologi radiasi ionizing pada bahan pangan dapat disimpulkan bahwa pemahaman konsep mahasiswa masih cukup rendah. Mahasiswa calon guru fisika masih perlu meningkatkan pemahamannya pada beberapa hal, diantaranya: a) Langkah-langkah teknik pengawetan bahan pangan menggunakan radiasi ionizing; b) Jenis bahan pangan dan dosis radiasi yang tepat; dan c) Syarat-syarat bahan pangan yang harus terpenuhi sebelum di iradiasi.

\section{DAFTAR PUSTAKA}

Anggraeni, L., Nurhayati. 2017. Analisis Kemampuan Berpikir Tingkat Tinggi Mahasiswa (Higher Order Thinking) dalam Menyelesaikan Soal Konsep Optika melalui Model Problem Based Learning. Jurnal Penelitian \& Pengembangan Pendidikan Fisika. 3(2) : 121-123.

Ermayanti., Dwi, S. 2016. Tingkat Kemampuan Berpikir Kritis Peserta Didik setelah Penerapan Model Pembelajaran Student Team Achievement Divisions (STAD) pada Siswa Sekolah Menengah Atas (SMA). Prosiding Seminar Nasional Quantum 2016. 176-177.

Irawati, Z. 2008. Perkembangan dan Prospek Proses Radiasi Pangan di 
Indonesia. Jurnal Teknologi dan Industri Pangan. 19(2) : 127.

Iskandar. 2009. Metodologi Penelitian

Kualitatif. Jakarta : Gaung Persada (GP. Press).

Yulianti, D., P, D. 2010. Pengembangan Kemampuan Berpikir Kritis Mahasiswa melalui Pembelajaran Problem Based Learning Instruction pada Mata Kuliah Fisika Lingkungan. Jurnal Pendidikan Fisika Indonesia. 6: 111.

Fitri, L., Rini, S. 2010. Kajian Pemanfaatan Radiasi Sinar Gamma (Co-60) pada Sistem Pengawtan Makanan Studi Kasus pada Serbuk Cabai. SIGMA. 13(2) : 118

Cahyani, A.F.K., Lauren, C.W., Risqia, A.P., Vicha, V.M., Agustin, K.W., Harsojo. 2015. Aplikasi teknologi Hurdle Menggunakan Iradiasi Gamma dan Penyimpanan Beku untuk Mereduksi Bakteri Patogen pada Bahan Pangan : Kajian Pustaka. Jurnal Pangan dan Agroindustri. 3(1) : 77-78.
Sari, N.M.P., Gusti, N.S., A.A.N.G. Pemanfaatan Radiasi Gamma Co-60 untuk Pemuliaan Tanaman Cabai (Capsicum annuum L.) dengan Metode Mutagen Fisik. Buletin Fisika. 21(2) : 48.

Jianto, L., Anita., Boisandi. 2020. Pengaruh Penerapan Lembar Kerja Siswa Berbasis Inkuiri Terbimbing Terhadap Kemampuan Metakognisi Siswa Pada Materi Hukum II Newton. Jurnal Berkala Pendidikan Fisika. 13(2) : 63.

Kalfat, A.J.J., Zubaidah, E. 2015. Iradiasi Sinar Gamma Pada Telur Ayam Broiler Sebagai Upaya Peningkatan Keamanan Pangan (Kajian Dosis Iradiasi Dan Penyimpanan Suhu $\left.4^{\circ} \mathrm{C}\right)$. Jurnal Pangan dan Agroindustri. 3(4) : 1443.

Putri, F.N.A., Agustin, K.W., Harsojo. 2015. Aplikasi Teknologi Iradiasi Gamma Dan Penyimpanan Beku Sebagai Upaya Penurunan Bakteri Patogen Pada Seafood : Kajian Pustaka. Jurnal Pangan dan Agroindustri. 3(2) : 350. 